\title{
The Organization of the Inner Nuclear Layer of the Rabbit Retina
}

\author{
Enrica Strettoi' and Richard H. Masland ${ }^{2}$ \\ 'Istituto di Neurofisiologia del C.N.R., Pisa, Italy; ${ }^{2}$ Program in Neuroscience and Howard Hughes Medical Institute, Harvard \\ Medical School, Boston, Massachusetts
}

The initial goal of this study was to establish an accounting of the major classes of cells present in the inner nuclear layer (INL) of the rabbit's retina. Series of 80-100 radial sections $1 \mu \mathrm{m}$ thick were cut from retinal blocks dissected at intervals along the vertical meridian. They were photographed at high magnification in the light microscope. By visualizing the initial segments of processes leaving the somata, we could identify each cell as a bipolar, amacrine, horizontal, or Müller cell. The identifications made by light microscopy were confirmed by electron microscopy of alternating ultrathin sections. On average, bipolar cells made up $41 \%$ of the total INL cells, amacrine cells $32 \%$, horizontal cells $1.5 \%$, and Müller cells $24 \%$. These fractions varied relatively little across the retina or among different animals.

We next immunolabeled the rod bipolar cells of wholemounted retinas with antibodies against protein kinase $C$, using FITC as the visualizing agent. The same retinas were counterstained with a DNA-binding probe that fluoresces at longer wavelengths. Serial optical horizontal sections of the double-labeled wholemounts were made by confocal microscopy. On average, rod bipolars accounted for $10 \%$ of the total INL cells. By subtraction, the cone bipolars made up $31 \%$ of the total cells. We conclude that cone bipolars substantially outnumber rod bipolars, even in a retina in which rods outnumber cones by more than 20:1.

Using the base of reference created here, a similar analysis can be carried out for other subclasses of retinal neuron. Because the analysis does not depend on absolute cell densities or corrections for shrinkage, data acquired by different histochemical techniques may be combined.

[Key words: bipolar, amacrine, horizontal, Müller, types]

How many different kinds of neuron does the retina contain? Despite much effort, the answer is still not known. The problem is most acute for bipolar cells, which exist in roughly a dozen known types, and amacrine cells, which may have as many as 20. Most of these cells may be stained by one or more standard methods. They have different connectivities and often different neurotransmitters; they play independent roles in the retina's

\footnotetext{
Received Mar. 7, 1994; revised July 11, 1994; accepted July 20, 1994.

We thank Michael Chiang and Anthony Castlebuono for help analyzing data, C.J. Jeon for PKC staining, Bob Morris for confocal microscopy, and Alberto Bertini and Piero Taccini for photographic work. This work was supported by NIH Grant EY05747 and by a CNR grant for Italy-USA bilateral projects.

Correspondence should be addressed to Dr. Richard Masland, Wellman 429 . Massachusetts General Hospital, Boston, MA 02114.

Copyright (C) 1995 Society for Neuroscience $0270-6474 / 95 / 150875-14 \$ 05.00 / 0$
}

function (reviewed by Kolb et al., 1981; Masland, 1988; Cohen and Sterling, 1990; Wässle and Boycott, 1991; Masland, 1992). What one does not know is how many more cell types there are-how many cells have not yet been encountered by current, essentially trial and error, methods.

The missing cells-those invisible to present staining techniques-are important. They represent unseen actors in the retina's circuitry. The responses of the retinal ganglion cells are controlled by all of the neurons afferent to them. If there are unseen elements afferent to the ganglion cell, our understanding of the creation of ganglion cell responses risks major error.

The work described here is a step toward a complete accounting of the retina's neurons. The goal is to learn how many cells of each functional class the retina contains, and how many of those can be accounted for by cells that can be specifically stained. Remarkably, such an accounting has rarely been carried out (Krebs and Krebs, 1987, 1989; Marc et al., 1990; Martin and Grünert, 1992). Aside from distinguishing neurons from glia, the major problem is tissue shrinkage during histological processing. Small differences in linear shrinkage (or errors in correcting for it) become large differences in the apparent density of the cells. This creates unacceptably large errors when tissues from different histochemical preparations or different animals are compared. Our first aim, therefore, was to create a base of reference that may be used to compare tissues prepared by a spectrum of histological methods.

Once a base of reference was available, we went on to partition the numbers of rod bipolar and cone bipolar cells. The rod bipolars were stained using antibodies against protein kinase $\mathrm{C}$. The same tissues were counterstained and the total nuclei of the inner nuclear layer counted using serial optical sections taken in a confocal microscope. Knowing the fraction of all INL cells that were bipolar cells and the fraction that were rod bipolars, it was possible by subtraction to learn the fraction of cone bipolars. In effect, the data allowed us to count a cell population (the cone bipolars) for which there is no specific stain.

\section{Materials and Methods}

Tissue preparation for serial section analysis. Three adult rabbits were anesthetized by intravenous injection of urethane $(1.5-2 \mathrm{~g}$ per $\mathrm{kg}$ of body weight). Animals one and two were New Zealand Red rabbits (body weight 6 and 4 pounds, respectively); animal three was a New Zealand White rabbit (body weight 3 pounds). The eyes were quickly enucleated and the anterior segments removed. The rabbits were then sacrificed by an overdose of the same anesthetic. The eyecups were immersed in a fixative containing $2.5 \%$ glutaraldehyde, $2 \%$ paraformaldehyde, and $1 \%$ acrolein in $0.1 \mathrm{~m}$ phosphate buffer, $\mathrm{pH} 7.2$. After $14 \mathrm{hr}$ fixation at $4^{\circ} \mathrm{C}$, the eyecups were extensively washed in cold phosphate buffer. They were dissected into horizontal strips along a vertical transect passing through the optic nerve head, in a ladder-like 
series. The strips were taken at $1 \mathrm{~mm}$ intervals and were $5-6 \mathrm{~mm}$ wide. Five or six strips were obtained from the dorsal part of the retina, and 11-13 strips from the ventral part. The samples were labeled D1 to D6 from the optic nerve head to the dorsal periphery, and V1 to V13 from the optic nerve head to the ventral periphery. The retinas used for serial section analysis originated from the left eye of animal one (here labeled as L1) and from the right eyes of animal two and three (labeled as R2 and $\mathrm{R} 3$, respectively).

The retina and choroid were separated from the sclera and washed in phosphate buffer. Retinas L1 and R3 were postfixed in $2 \%$ osmium tetroxide, while retina $\mathrm{R} 2$ was postfixed in a mixture of $1 \%$ osmium tetroxide and $1.5 \%$ potassium ferrocyanide. All the retinas were then stained en bloc with uranyl acetate, dehydrated in ethanol, and embedded flat in Epon-Araldite.

Light microscopy. Light microscopy of serial sections was performed on two dorsal blocks (D2 and D6), and five ventral blocks (V3, V4, V6, V9, and V12) from animal one (L1). Analysis of locations V3, V6, and V9 was performed in retinas $R 2$ and $R 3$ as well. In each retina, the position of the visual streak was assessed from the thickness of the outer nuclear layer. As expected, the peak of the streak was located 3-4 mm ventral to the optic nerve head.

Series of 80-120 vertical $1 \mu \mathrm{m}$ sections were obtained from each block using an LKB ultratome $\mathrm{V}$ ultramicrotome equipped with a diamond knife. Consecutive ribbons of 8-10 sections were collected on glass slides, dried on a hotplate and stained with Epoxy tissue stain (Electron Microscopy Sciences, Fort Washington, PA). The sections were examined with a Zeiss Axioplan microscope; a selected area was photographed in each section with a $100 \times$ Plan Neofluar objective, using differential interference contrast optics and Kodak TMax $100 \mathrm{film}$. Micrographs were printed at a final magnification of $1600 \times$. The number of serial sections photographed at each retinal location was chosen so that the retinal area examined contained at least 200 INL cells; to compensate for variations in cell density, retinal areas examined ranged from over $17,000 \mu \mathrm{m}^{2}$ in peripheral areas to a minimum of $5000 \mu \mathrm{m}^{2}$ in the central areas of retina $\mathrm{R} 2$, which had the highest cell density of all the samples.

Each cell present in the serial micrographs was identified. A starting cell was identified in a micrograph; if a defining characteristic for that cell (clear evidence of a process exiting vitreally or sclerally) was apparent, a tentative identification was made. The cell class and a number were assigned to that cell. Adjacent micrographs were then used to confirm the identification. If a defining characteristic was not apparent in the first micrograph, the cell was numbered and adjacent micrographs were searched for a defining characteristic until one was clearly established. At that point, the cell's class was also labeled. Once the cell had been clearly identified, it was followed to its full extent and labeled in all the sections. The process was then repeated for another cell, usually an adjacent one, until all cells within the field had been identified. The reference micrograph was then advanced to one deeper in the series and the process was repeated for all newly encountered cells until all cells had been identified. At the beginning and end of the series, it was necessary to establish a criterion for the inclusion of partially sectioned cells. This was done by the traditional method of excluding partly sectioned cells at the top of the series and including partly sectioned cells at the bottom. A total of approximately 7000 cells were identified in the semithin sections.

Electron microscopy. We cut and examined five mixed series, in which 8-10 serial ultrathin sections and a single $1 \mu \mathrm{m}$ section were examined at the electron microscope and the light microscope, respectively. This allowed the simultaneous visualization of groups of cells at both the ultrastructural and morphological level. Such mixed series were obtained from blocks V4, V6, and V9 of retina L1, and in block V4 of retina $R 2$. The images were used to confirm our light microscope criteria for identifying the different cell classes.

To confirm at the electron microscope the numerical distribution of cells in the INL obtained with light microscopy, serial section analysis was performed at the electron microscope for block V4 of retina $\mathrm{L} 1$. Such an analysis seemed particularly important near the visual streak, where the high density and small size of the cells made identification at the light microscope level the most difficult. A series of 200 ultrathin sections (average thickness, $100 \mathrm{~nm}$ ) was cut from block L1 V4. Ribbons of 10 sections were collected on single-hole grids coated with formvar, stained with uranyl acetate and lead citrate, and examined with a Jeol 1200 EXII electron microscope. A selected area was photographed at a magnification of $2500 \times$. Four negatives were taken of one of every three sections to cover the ONL, the INL, and the sclcral half of the IPL. Pictures were printed at a final magnification of $7500 \times$ and assembled in montages. The retinal area examined with the EM was about $3500 \mu \mathrm{m}^{2}$.

Protein kinase immunocytochemistry and confocal microscopy. The retinas of two New Zealand White rabbits were dissected from the eyes under Ames medium (Sigma, St. Louis, MO) and fixed with 4\% paraformaldehyde in $0.1 \mathrm{M}$ phosphate buffer, for $2 \mathrm{hr}$, at $4^{\circ} \mathrm{C}$. The retinas were rinsed in Tris buffer $0.05 \mathrm{M}, \mathrm{pH} \mathrm{7.2,} \mathrm{then} \mathrm{quickly} \mathrm{frozen} \mathrm{by} \mathrm{im-}$ mersion in liquid nitrogen and thawed. They were preincubated for 12 hr in $5 \%$ normal horse serum and $0.5 \%$ Triton $\mathrm{X}-100$, followed by incubation in anti-protein kinase $\mathrm{C}$ antibody (Amersham, Arlington Heights, IL, clone MC5 Rpr.536) for $3 \mathrm{~d}$, with $5 \%$ serum and $0.5 \%$ Triton. The antigen-antibody complex was revealed by the ABC method (Vector, Burlingame, CA) using a biotinylated secondary antibody (horseantimouse IgG), followed by Avidin D conjugated with fluoresceinisothiocyanate (Avidin-FITC, peak emission $519 \mathrm{~nm}$ ). The same wholemounts were counterstained in a $1 \mu \mathrm{M}$ solution of ethidium homodimer (Molecular Probes, Eugene, OR), a DNA-binding molecule that stains all nuclei and fluoresces in the long wavelengths (peak emission, 626 $\mathrm{nm})$

For quantitative studies of the rod bipolars, conventional light microscopy was used, because the density of cells is low and large fields needed to be photographed. Micrographs were taken along a vertical transect passing through the optic nerve head at $1 \mathrm{~mm}$ intervals. At each interval, a field of $90,000 \mu \mathrm{m}^{2}$ was photographed: the rod bipolars were counted in prints of these fields at a total magnification of $830 \times$. To establish the total density of cells at corresponding locations, confocal microscopy was used. At six locations along the same transect (four for the second retina) serial horizontal optical sections showing the ethidium-stained nuclei were made. The optical sections had a focal depth of slightly less than $1 \mu \mathrm{m}$, and were $1 \mu \mathrm{m}$ apart. These series covered the total thickness of the inner nuclear layer and a retinal surface of about $17,000 \mu \mathrm{m}^{2}$. Prints were made at a total magnification of 1600 $2300 \times$. Every nucleus in the layer was identified from the prints, using methods similar to those described for serial ultrathin identifications of subtypes (but without the requirement for identifying the type of cell). It was not difficult to count the cells unambiguously in these series. The greatest uncertainty arose when two cells were located immediately above and below each other with no lateral displacement. However, these instances were few, and it was possible with practice to distinguish the cells clearly; either the nuclei had different shapes, or there was a clear "figure 8" appearance in depth, because of the decreasing diamctcrs of the nuclei near the junction between the two cells.

To confirm the density of rod bipolar cells established from the low magnification images, confocal images of the PKC-stained cells and ethidium-stained nuclei were made at every location at which the nuclei were counted. The density of rod bipolar cells in these images was found to be the same as had been established from the low magnitication counts. These images also allowed a direct verification of the relative proportions of rod bipolar cells and total bipolar cells, since they could be readily superimposed by the confocal microscope (see Fig. 6).

\section{Results}

Our initial goal was to classify all of the cells in small retinal volumes from light microscope images of serial semithin sections. It seemed apparent from the beginning that this would be possible, because processes were readily visualized leaving the cell bodies. This was confirmed by examination of mixed light and electron microscope series (Fig. 1). In the light microscope (inset) thin processes can be seen leaving the scleral aspect of certain cell bodies. Electron microscopy confirms that they are, indeed, bipolar cell dendrites. Similarly, processes exiting amacrine cells are clearly identified in both micrographs.

Note also that the electron or stain densities of cell cytoplasm and nuclei were consistent between the light and electron microscope images. For example, both components of the Müller cell appeared particularly dense. As will be described below, there were a number of consistent differences in the densities of the different cell classes; these were a supplement to identi- 


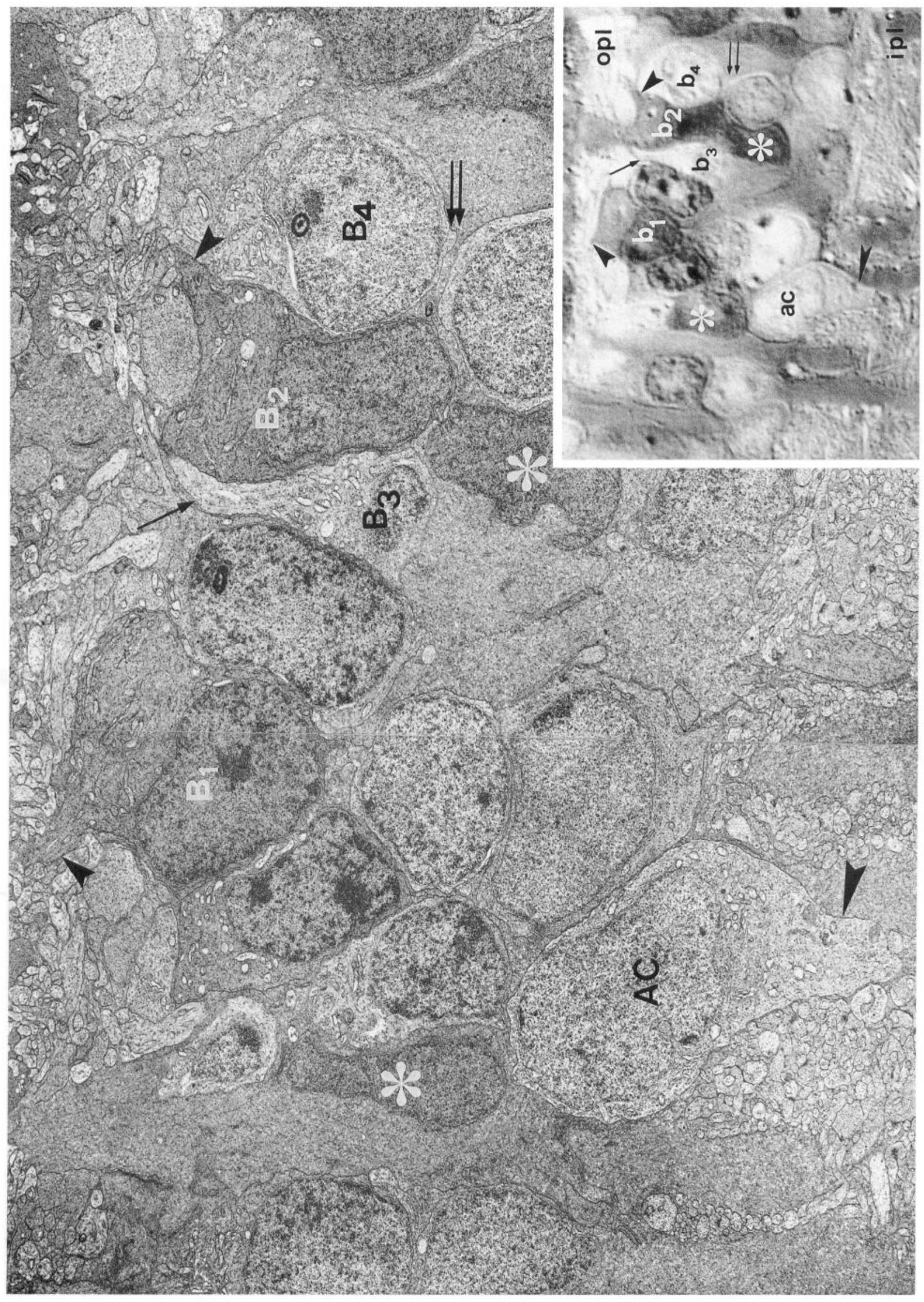

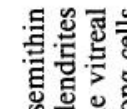

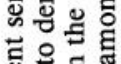

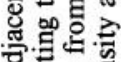

ज.

둥

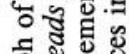

율

ㅇํㄴ

西宫。

둥은

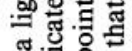

응

贾

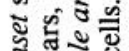

.

둥을

远政

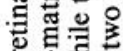

눈

대워

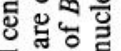

ฮีำำ

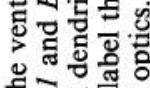

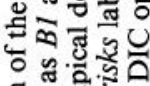

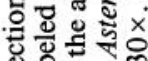

巡这

品

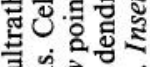

至

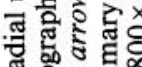

잉

ธํㅡㄹ

옹

政

ฮ

政

단등

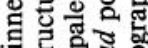

o 5 .

능 है

등ํㅇ

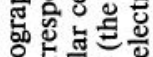

녕 융

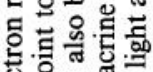

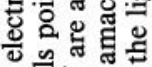

잉 동

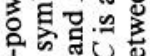

我

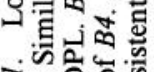

की० के

影

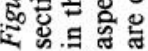



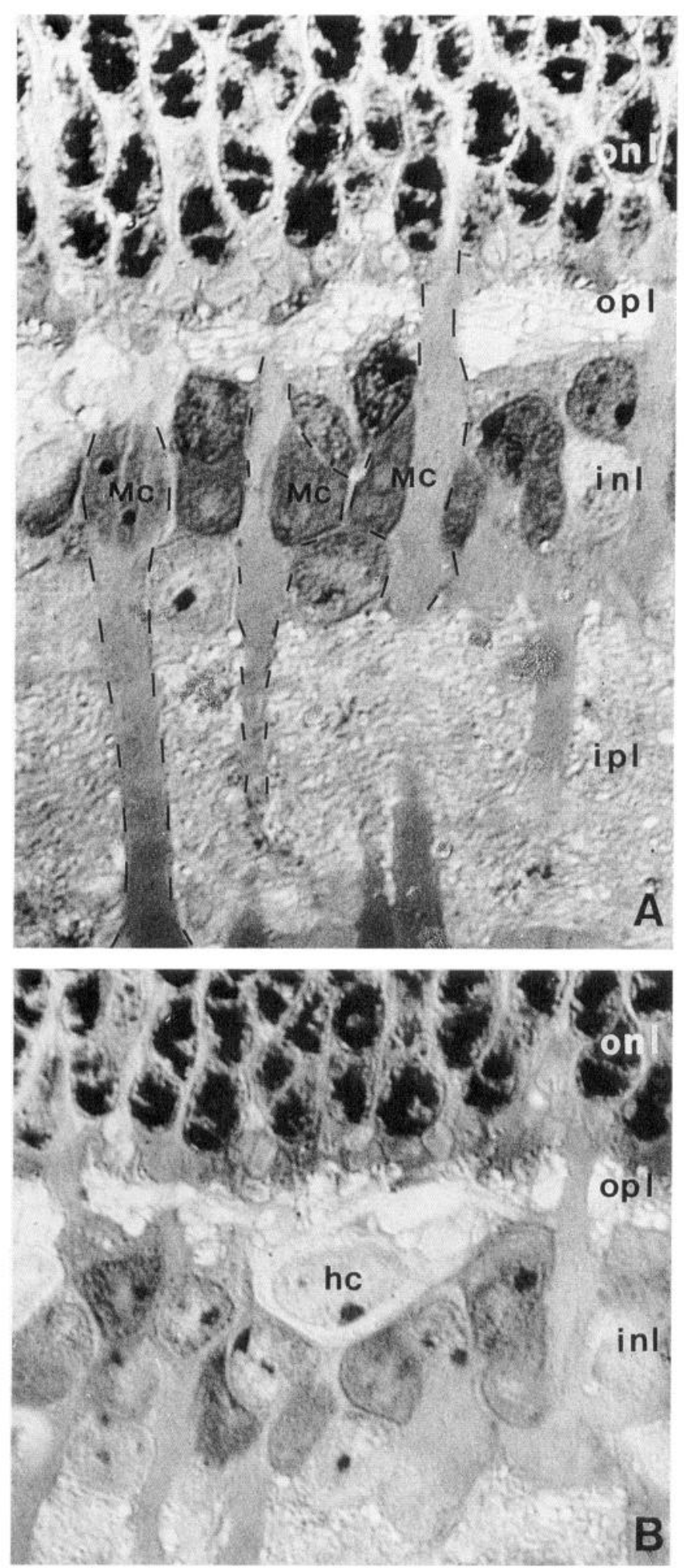

Figure 2. A, Light micrograph of radial, semithin section illustrating the morphology of three Müller cells $(M c)$. Their large cell bodies occupy the centralmost row of the inner nuclear layer $(I N L)$. They display dark nuclei with dense nucleoli. The stalks typical of Müller cells cross the inner and outer plexiform layers (IPL and $O P L)$. $I N L$, inner nuclear layer; $O N L$, outer nuclear layer. $B$, Typical morphology of a horizontal cell body $(h c)$ : the cell has a pale matrix, a large nucleus with a prominent nucleolus, and a location at the scleral border of the INL. Magnification: $1750 \times$. DIC optics. fication of the processes for classifying the cells. The differences in density were also useful for following individual cells through the serial micrographs.

\section{Serial reconstruction of the inner nuclear layer}

Müller cells were readily identified. Their nuclei were large, dark, and elongated. In the serial sections, it was easy to trace the continuity between the cell bodies of Müller cells and their characteristic stalks, which cross the inner plexiform layer and part of the outer (Fig. 2A). Müller cell nuclei were located preferentially in the central part of the inner nuclear layer, though because of their large size they occupied more than one row of cell bodies.

Horizontal cells displayed a large cell body with pale matrix, a large nucleus, and a prominent nucleolus. They were invariably located at the outer border of the INL (Fig. $2 B$ ). Thick, pale processes were observed to emerge from the cell bodies and run a tangential course in the OPL. Axonless and axonbearing horizontal cells appear very similar in radial sections taken in the proximity of the cell body; we did not make any attempt to distinguish between them.

Bipolar cells, by definition, have dendrites emerging from the scleral aspect of the cell body and directed toward the OPL; and have an axon emerging from the vitreal side of the cell body and directed toward the IPL. Both large-caliber dendrites and axons could be identified unequivocally at the light microscope (Fig. 3A-F). Some dendrites had thick apical processes (Fig. $3 A$ ). These were usually connected to small-size cell bodies, displaying a pale matrix: others had thinner processes, more often emerging directly from large-size cell bodies with a dark matrix (Fig. $3 F$ ). The bipolar axons could often be followed to their parent cell bodies within a single semithin section (Fig. $3 B-E$ ). Most of the bipolar cells with a dark matrix were rod bipolar cells, as illustrated in Figure $3 E$ where the identity of the cell could be confirmed by the large size of the axonal endings and their stratification at the vitreal border of the IPL. Cell bodies of rod bipolar cells were usually larger than those of cone bipolars, and located more sclerally. Seen in isolation, their axons were more difficult to distinguish, since the density of their matrix appeared very similar to that of Müller cell cytoplasm. However, their dendrites were clearly visible against the pale background of the OPL (Fig. $3 F$ ), making identification always possible.

Amacrine cells were identified by the presence of dendrites originating from the cell body and oriented toward the IPL, in the absence of processes directed toward the OPL. Dendrites of amacrine cells had different sizes and orientations. With light microscopy, the thickest dendrites could be resolved clearly (Fig. $4 A-F)$. Large-size amacrines, with stout processes, were easy to identify (Fig. 4A). At times, thin dendritic ramifications were also visible. Some amacrine cells were characterized by large primary dendrites with a pale matrix running a radial course in the IPL (Fig. $4 B$ ); other dendrites were considerably thinner and oriented tangentially (Fig. $4 C, F$ ). Some amacrine cells had large primary processes with a dark matrix, crossing the IPL vertically and emerging from ovoid cell bodies protruding into the scleral part of the IPL (Fig. $4 E$ ); such morphological features are typical of AII amacrine cells.

With few exceptions, cell bodies that occupied the most vitreal layer of the INL were found to belong to amacrine cells. In the central retina, where the INL included four to five rows of cell 
Table 1. Distribution of cell types at different retinal locations in three retinas (R1, L1, and R3)

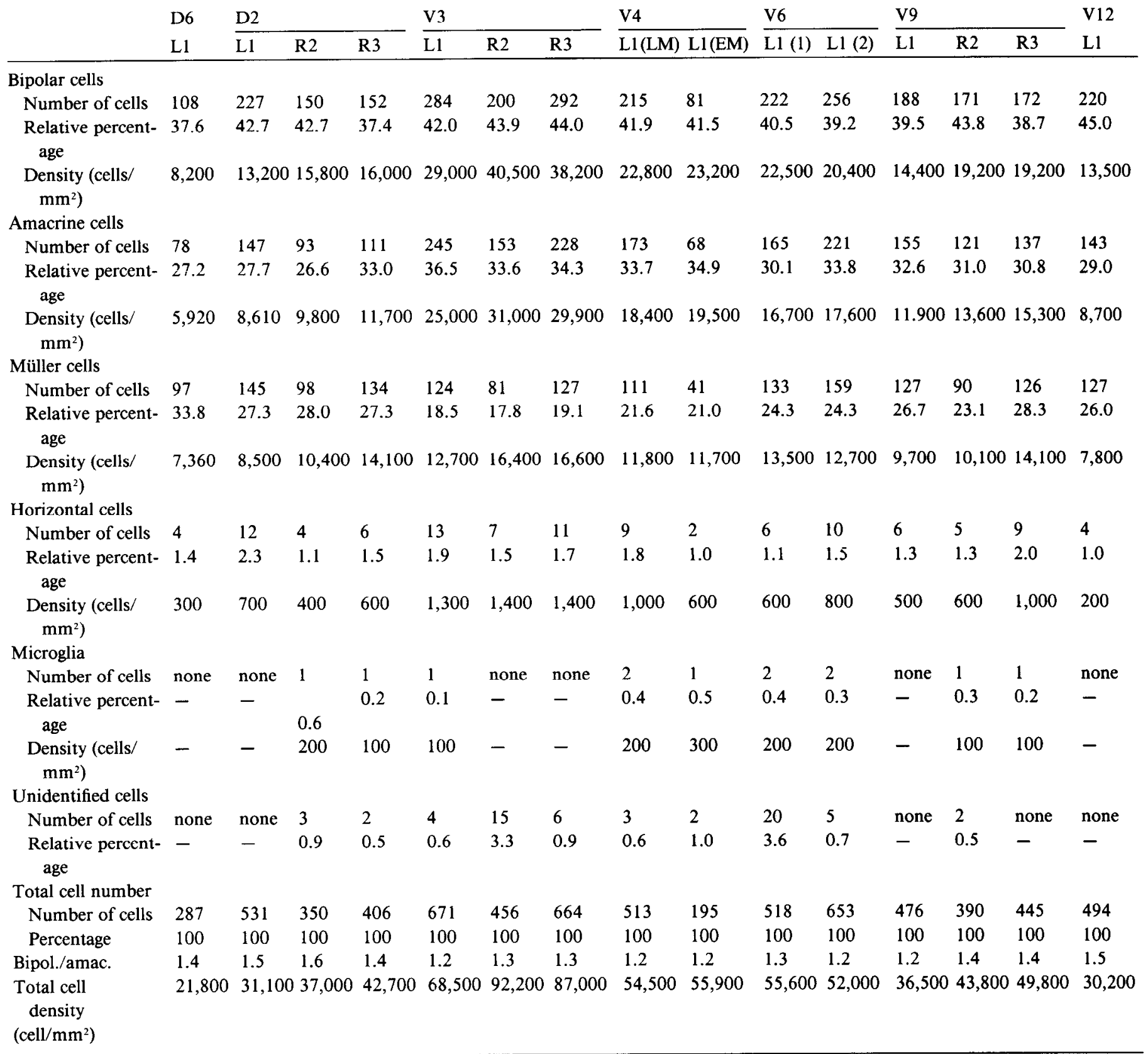

bodies, amacrine cells occupied two layers; the most scleral contained bipolar and Müller cell bodies as well.

The nuclei of most of the amacrines and bipolars were displaccd to the polc opposite that from which dendrites emerge. In a sectioned bipolar cell, the nucleus lay vitreal to the center of the cell body, while in an amacrine cell it lay more sclerally (compare Fig. $3 \mathrm{~A}$ to Fig. $4 \mathrm{C}$ ). Also, amacrine cell nuclei were often indented. The position of the cell body within the INL and shape and position of the nucleus within the cell thus represented additional criteria for identification. Since amacrine

Figure 3. Light micrographs of radial, semithin sections illustrating the morphological features of bipolar cells that allow their identification. Dendrites leave the somata of bipolar cells $(b c$ and $r b c)$ heading toward the OPL $(A, F:$ arrowheads; $C$ : arrow). Bipolar axons are also clearly visible in the process of emerging from the parent cell bodies $(B, C, D$, and $E$ : large arrowheads). Bipolars shown in $A-D$ have a pale matrix. The two cells illustrated in $E$ and $F$ have a dark matrix and are rod bipolars $(r b s)$, as shown by the large size and deep level of stratification in the IPL of the axonal endings ( $E$ : small arrowheads). Magnification: $1750 \times$.

Figure 4. Light micrographs of radial, semithin sections illustrating the morphological features of amacrine cells ( $a c)$ used for their identification. Arrowheads point to amacrine dendrites, different with respect to size and cytology, emerging directly from the cell bodies to penetrate into the IPL with various courses. Amacrine cell bodies occupy the vitrealmost portion of the INL. Magnification: $1750 \times$. 

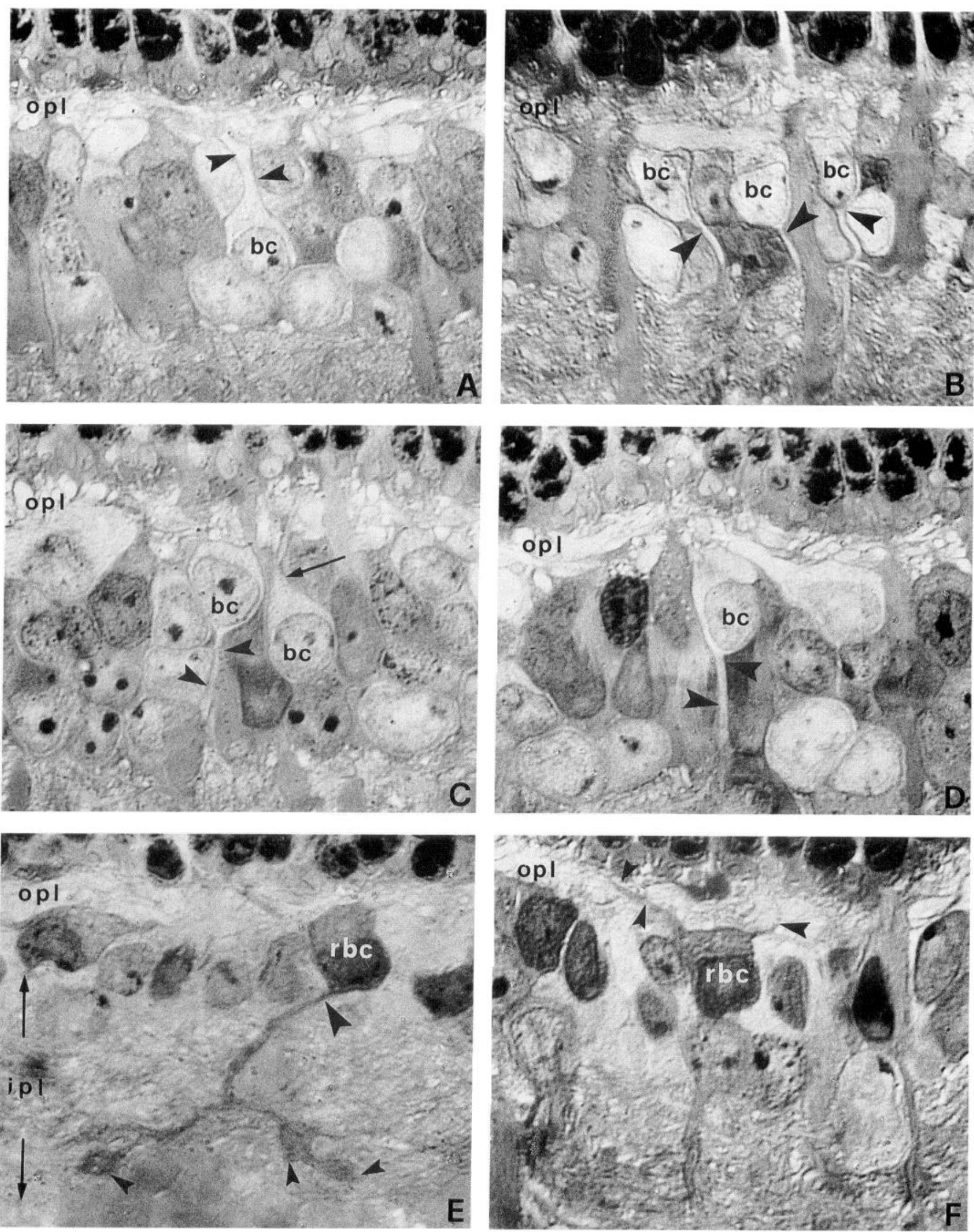


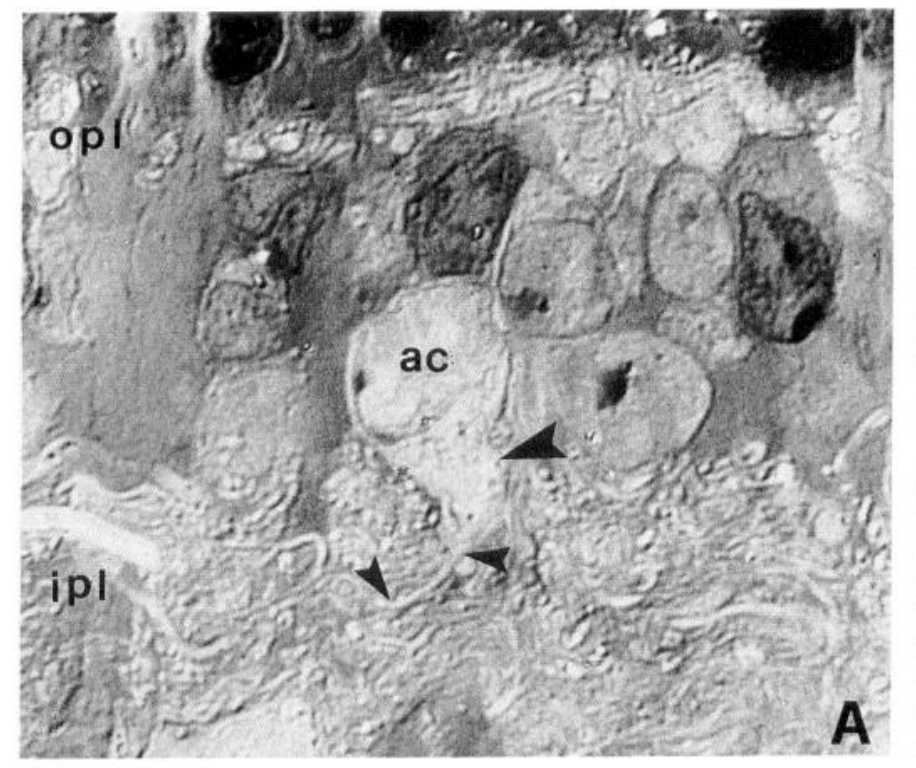

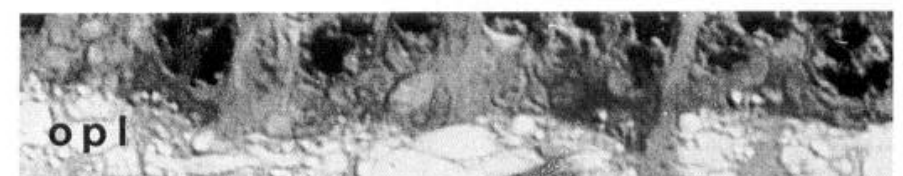
S.

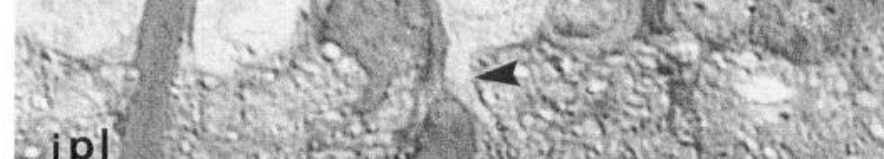
ipl

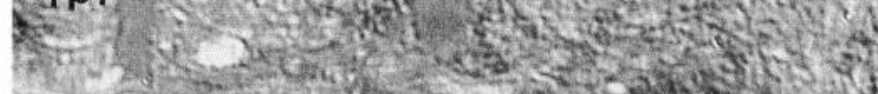

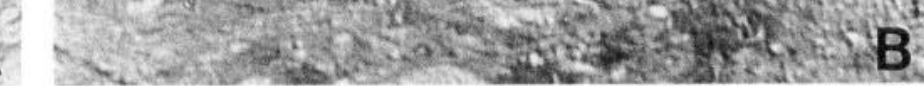
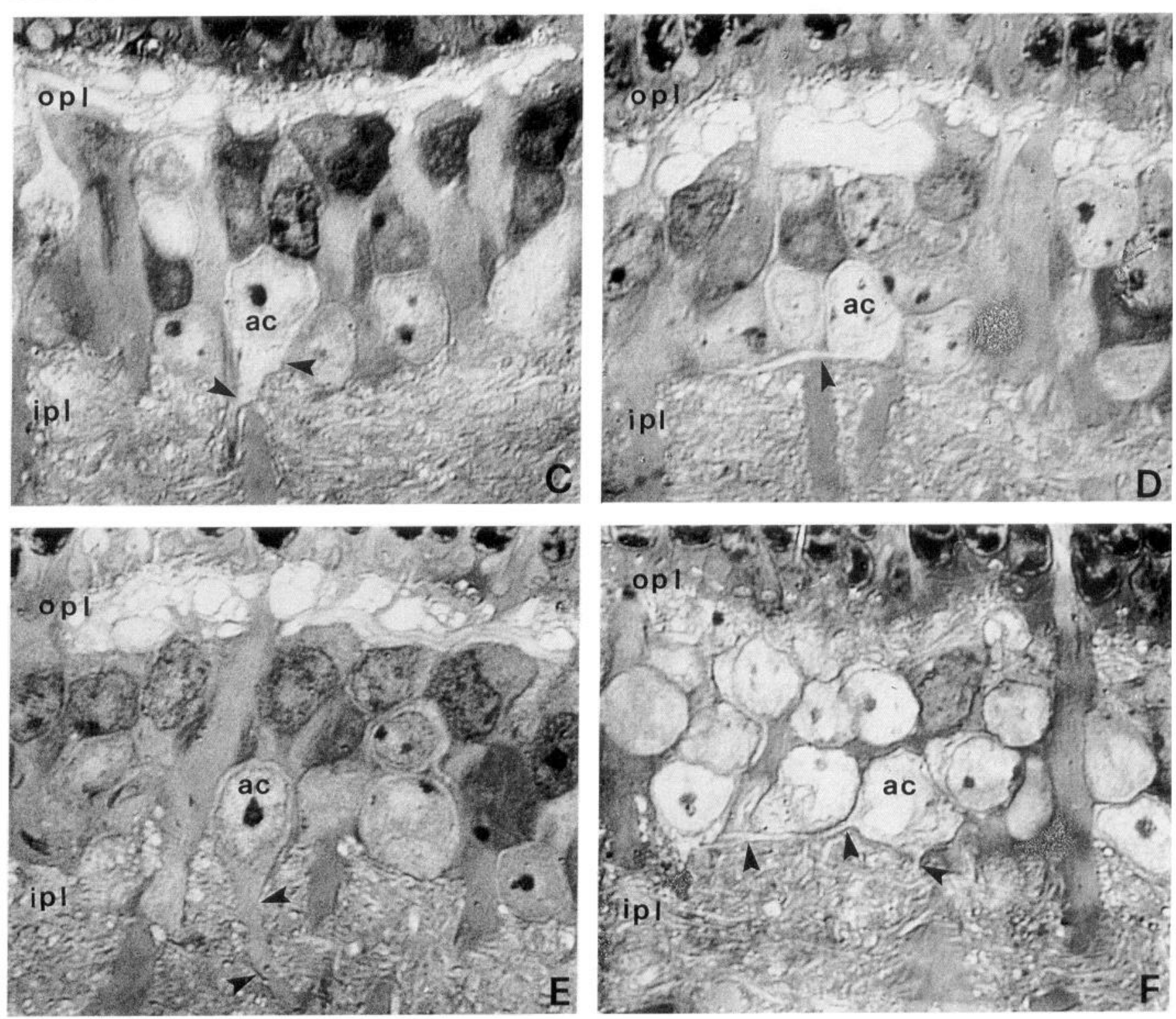

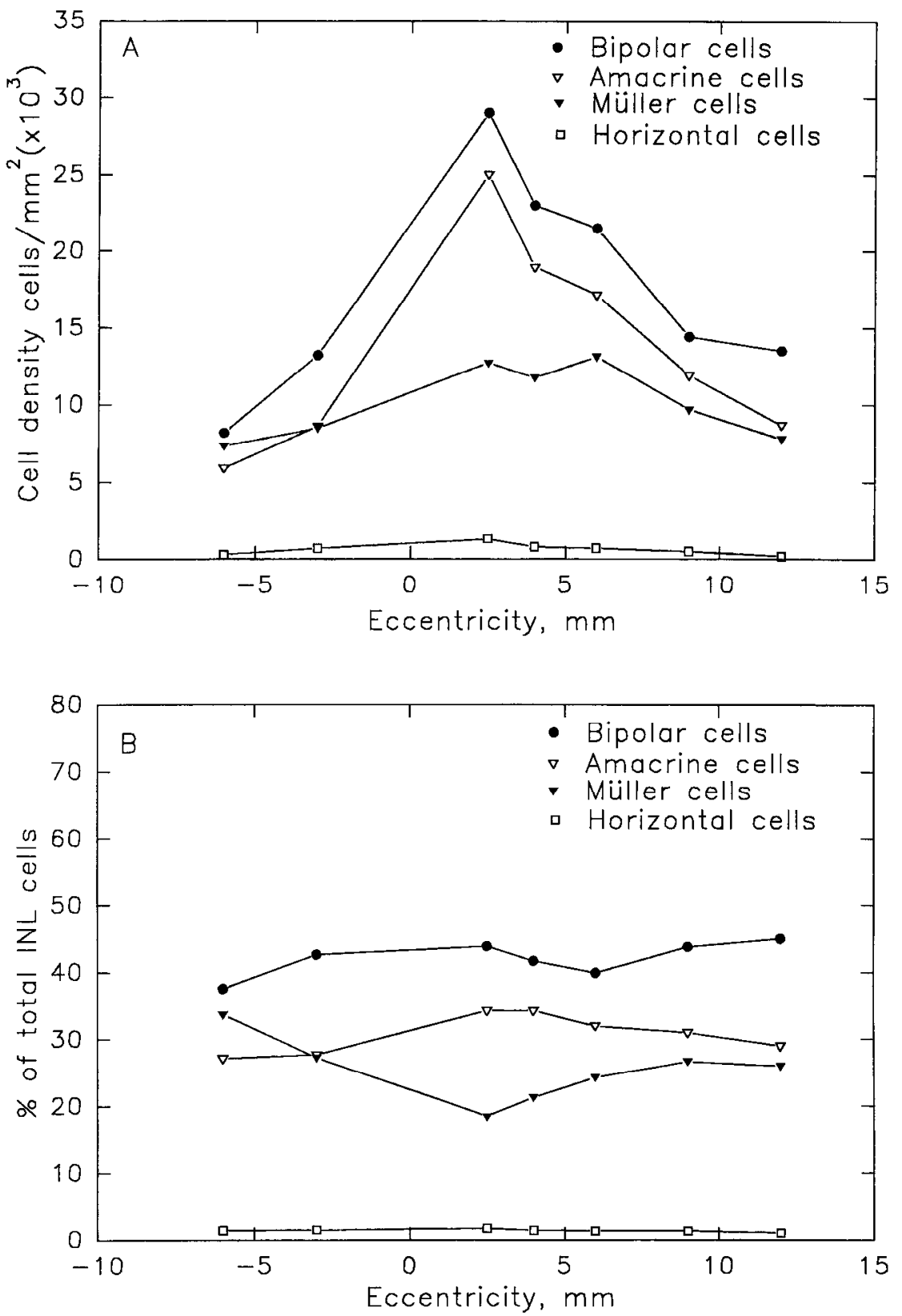

Figure 5. $A$, Densities of the retinal cells as a function of distance from the optic nerve head (retina L1). $B$, Relative frequencies of the cells as a function of eccentricity (retinas L1, R2, and R3).

cells displayed variable cytological features (dark or pale matrix, presence of single or multiple nucleoli, etc.), and could vary in size over a large range, cytology and size could not be taken as valid criteria for identification. In a few cases (mostly in the central retina), cell bodies were encountered without visible processes connected to them; their small size and their location in the middle of the INL were ambiguous features shared by amacrine and bipolar cells. Such cells were probably amacrines with dendrites below the resolution of the light microscope, but we labeled them as unidentified. Note that identification was always done through positive criteria. This was possible because dendrites of bipolar cells (either in the form of a large, apical process, or of multiple, thinner dendrites) were clearly visible. Dendrites in the OPL are the surest criterion for discrimination between amacrine and bipolar cells at the light microscope, since at times primary dendrites of amacrines could resemble axons of bipolar cells.

Examples of other cell classes were occasionally encountered.

Figure 6. $A$, The INL of a retina stained with ethidium homodimer. Confocal micrograph, long-wavelength filter. The plane of focus is at the outer margin of the INL. Most of the nuclei at this level belong to bipolar cells. $B$, Same field as in $A$, but observed with short-wavelength filter, showing rod bipolar cells stained with PKC histochemistry. Their unstained nuclei can be identified in $A$, and are labeled with corresponding numbers. Note that they represent a minor fraction of all the nuclei shown in $A$. The location was about $12 \mathrm{~mm}$ ventral to the optic nerve head. Scale, $10 \mu \mathrm{m}$. 

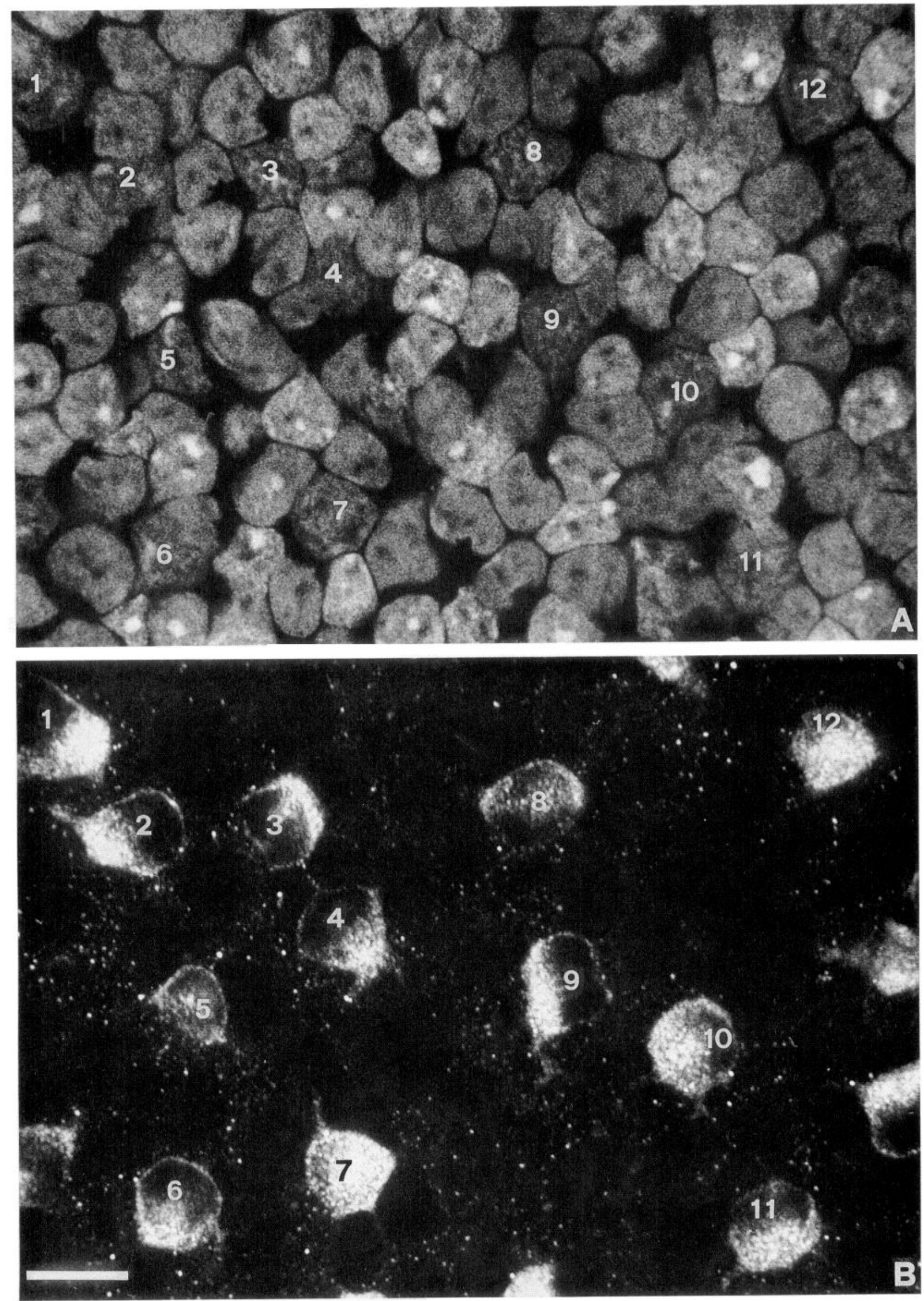


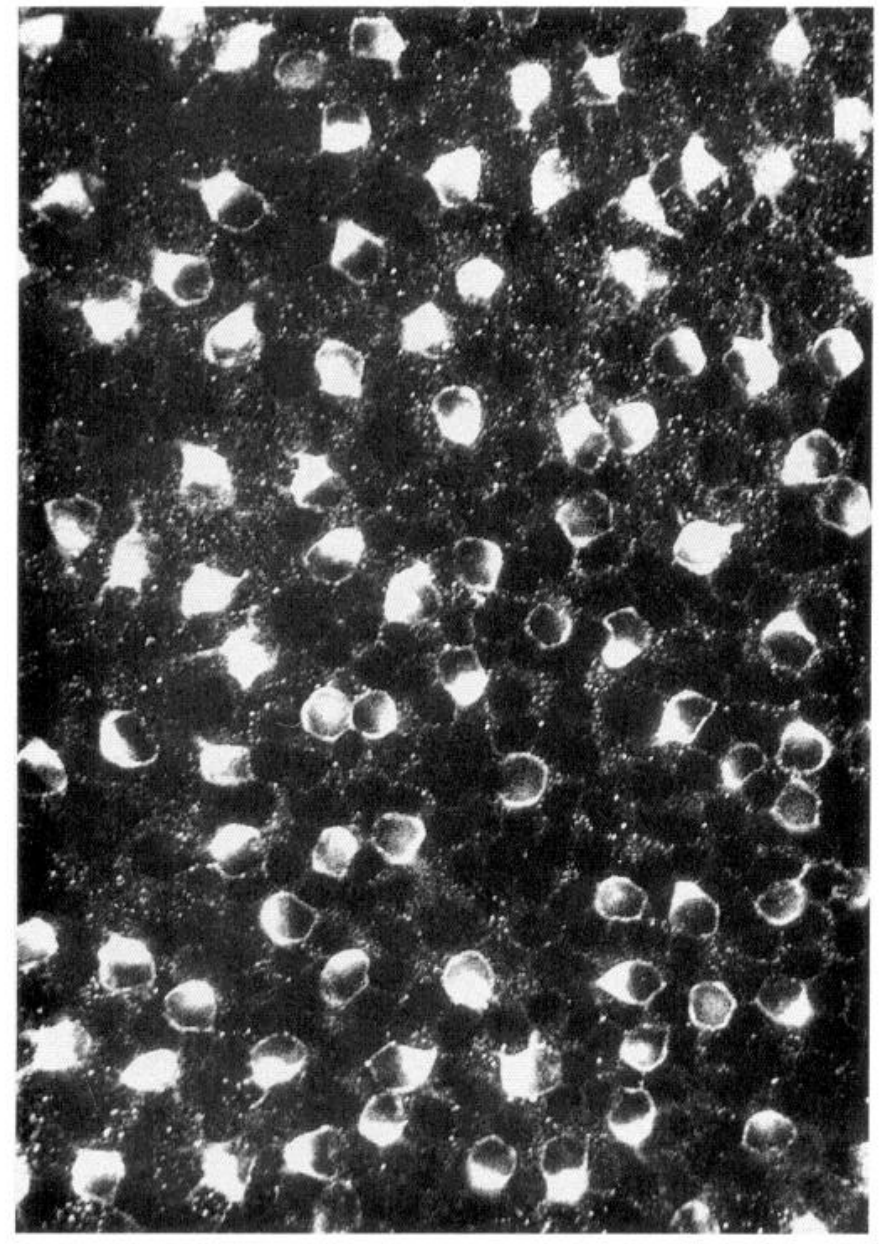

Figure 7. Low-power confocal micrograph illustrating the distribution of rod bipolar cells in the ventral periphery (same location as in Fig. 6). Magnification: $480 \times$.

Cell bodies of microglial cells could be observed in several tissue blocks, though in very low number. They were small cells, with a large, dark nucleus surrounded by an halo of pale cytoplasm (Boycott and Hopkins, 1981; Schnitzer, 1989). Their cell bodies were located within the IPL. (Their cytological features and identity were confirmed at the electron microscope.) Occasionally, the cell body of a displaced ganglion cell was found in the most vitreal layer of the INL. Their identity was indicated by their very large size and abundance of cytoplasm and endoplasmic reticulum, giving their matrix a punctate appearance typical of normally placed ganglion cells in semithin sections. They also had a large nucleus with a prominent nucleolus. Interplexiform cells have been described in the rabbit retina as having very thin dendrites directed toward the OPL (Oyster and Takahashi, 1977). We would probably have missed such dendrites and classified the cells as amacrines or as unidentified cells. Even in the unlikely event that those interplexiform cells were mislabeled as bipolar cells, the error was negligible, since their density is very low.

\section{Topographic distribution of cell classes}

At each of the retinal locations chosen, all the INL cells within a selected area were identified and counted. Table 1 and Figure 5 show the results. The absolute density of the three neuronal cell classes rose from a near-plateau in the periphery to a sharp peak in the visual streak (Fig. $5 A$ ). Despite the increase in the total numbers of cells in the visual streak, the fractional distribution of the neuronal cell classes remained relatively constant across the retina. The average percentage of bipolar cells was $41.4 \%$, while amacrine cells represent $31.6 \%$ and horizontal cells $1.4 \%$ of the total INL cells (Fig. $5 B$ ).

The situation for Müller cells was slightly different, because the absolute density of Müller cells does not rise as much as the density of neurons in the visual streak (Robinson and Dreher, 1990; Jeon and Masland, 1993). Outside the visual streak, Müller cells represented on average $26 \%$ of the cell bodies that make up the INL. In the central retina, their fraction dropped to 18.5$21 \%$.

Note that the relative fractions of the different cell classes (Fig. 5B) were more constant from sample to sample and animal to animal than the absolute numbers (see Table 1). Unavoidable small differences in tissue handling or shrinkage may have contributed to the variability in absolute numbers. A larger source of variability was the difference in size among the retinas. In rabbits (and many other animals) the eye continues to grow throughout much of the animal's life (Mastronarde et al., 1984; Dann et al., 1988; Fernald, 1990). The retina expands as the eye grows. However, the number of retinal cells does not increase; the density of retinal cells, therefore, falls as the eye expands. Animal three was the smallest animal. It had the smallest retina and the highest density of retinal cells. However, the relative proportions of the four cell types were very close to those for the other two animals.

Electron microscopy of serial sections was performed to confirm the numerical distribution of INL cells obtained by light microscopy. This seemed particularly important in the central retina, where the small size and dense packing of cells make identification more difficult. The numerical results in the LM and EM series obtained were extremely close (see Table 1, L1 V4), confirming the validity of the criteria adopted for identification. (It is also clear that such an analysis could not have been performed with electron microscopy alone, since the number of sections and prints necessary for an adequate sample of cells is prohibitive).

\section{Rod and cone bipolars as fractions of the total INL cells}

The distribution of the broad classes of cells across the retina can be used to learn the fraction occupied by individual types of cells, provided that specific staining methods are available for them. Knowing the fraction of INL cells occupied by bipolar cells, for example, we could address the question: what fraction of all bipolar cells are rod bipolars?

The first step was to compare the total number of nuclei in the INL with the total number of cells stained using antibodies against protein kinase C (PKC) (Negishi et al., 1988; Vaney et al., 1991; Wässle et al., 1991). Staining of the nuclei by ethidium is shown in Figure $6 A$. PKC staining of the rod bipolar cells in the same field is shown in Figure $6 \mathrm{~B}$. The density of the rod bipolar cells was established by counting them in low-power micrographs, such as the one illustrated in Figure 7 . The total cell density in the INL was established by counting the ethidiumstained nuclei, using serial optical sections through the layer made by confocal microscopy (Fig. 8). The results are shown in Figure $9 A$ and $B$.

The density of rod bipolar cells in one retina ranged from 5450 cells $/ \mathrm{mm}^{2}$ near the peak of the visual streak to about 2400 

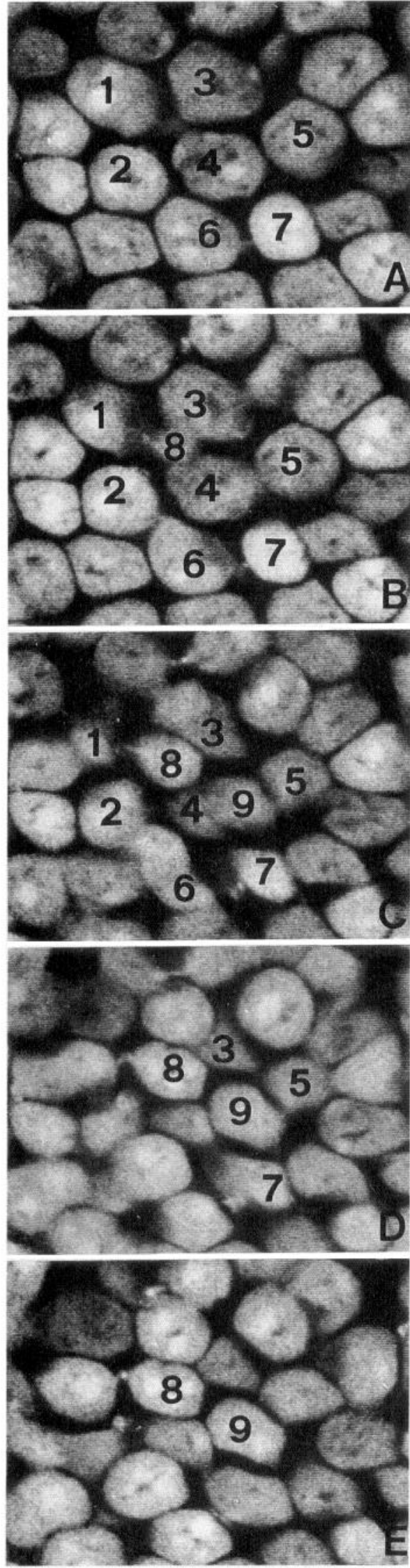

Figure 8. Through-focus, confocal series illustrating a group of nuclei of INL cells stained with ethidium homodimer, and labeled from 1 to cells $/ \mathrm{mm}^{2}$ in the dorsal and ventral periphery (Fig. 9A). These values agree well with those reported by Young and Vaney (1991). The total density of cells in the INL ranged from 69,418 cells $/ \mathrm{mm}^{2}$ near the visual streak to approximately 20,566 cells/ $\mathrm{mm}^{2}$ in the dorsal periphery and 24,988 cells $/ \mathrm{mm}^{2}$ in the ventral periphery (Fig. $9 B$ ). In the other retina examined, the density of rod bipolar cells ranged from 4705 cells $/ \mathrm{mm}^{2}$ in the central retina, to below 2000 cells $/ \mathrm{mm}^{2}$ in the dorsal periphery and 2935 in the ventral periphery. In the same retina, the total density of cells in the INL ranged from 62,170 cells $/ \mathrm{mm}^{2}$ near the peak of the visual streak, to 16,276 cells $/ \mathrm{mm}^{2}$ and 29,141 cells $/ \mathrm{mm}^{2}$ in the dorsal and ventral periphery, respectively. Thus, in both retinas, rod bipolars represent about $7.7 \%$ of all the INL cells in the central retina, $12 \%$ in the dorsal periphery, and $10 \%$ in the ventral periphery (Fig. 9C).

From analysis of semithin sections we know that bipolar cells make up $43 \%$ of the total cells of the central retina (V3 and V4, Table 1). Combining the data, rod bipolars amounted to $18 \%$ of all bipolar cells in the central retina. In the dorsal periphery, bipolars were $38 \%$ of the total cells, and rod bipolars $32 \%$ of all bipolar cells. In the ventral periphery, bipolar cells make up $45 \%$ of the total cells in the INL, and rod bipolars $22 \%$ of all bipolar cells. This means that in the central retina there are four to five cone bipolars for each rod bipolar. In the ventral periphery, the ratio is $3.5: 1$ and in the dorsal periphery, the ratio is about 2:1 (Fig. 9C).

It was somewhat unexpected that rod bipolar cells should form a minority of all bipolars in a rod-dominated retina. However, the finding is quite evident in comparing the high magnification confocal images shown in Figure 6. The plane of focus in both micrographs is at the outer margin of the inner nuclear layer, the level of rod bipolar somata. Horizontal cells comprise a negligibly small fraction of INL cells, while amacrine cells are almost exclusively located at the bottom of the INL. Although nuclei of a few Müller cells reach the outer row of the INL, the vast majority of stained nuclei at that level belong to bipolar cells. Even a casual comparison of Figure $6, A$ and $B$, shows that rod bipolars occupy less than one-third of the total bipolar cell mosaic.

\section{Discussion}

A striking feature of our results was the limited variability between different eyes and different animals, once the data were expressed as fractions of the different cell classes rather than absolute densities (Table 1). Among individual rabbits (indeed, among individuals of all mammalian species) there is substantial variation in the density of retinal cells (Repka and Quigley, 1989; Curcio and Allen, 1990; Robinson and Dreher, 1990; Masland et al., 1993). In addition, spurious variability is introduced during tissue preparation. However, the interlocked arrays of retinal neurons - the individual microcircuits that mediate retinal function - are remarkably constant. This constancy is highlighted when one expresses the numbers of retinal cells relative to each other, rather than in terms of spatial density. The reason is probably that the individual elements of each

9. $A$, The nuclei of cells $1-7$ are clearly distinguishable. $B$, The nucleus of cell 8 is now interposed between 3 and 4 . Nuclei 1 and 7 decrease in diameter. $C$, Nuclei $1-7$ decrease visibly, while 8 enlarges, and a new nucleus $(9)$ appears. $D$ and $E$, Nuclei $1-7$ progressively disappear, while 9 and 8 reach their maximum size. Magnification: $1385 \times$. 

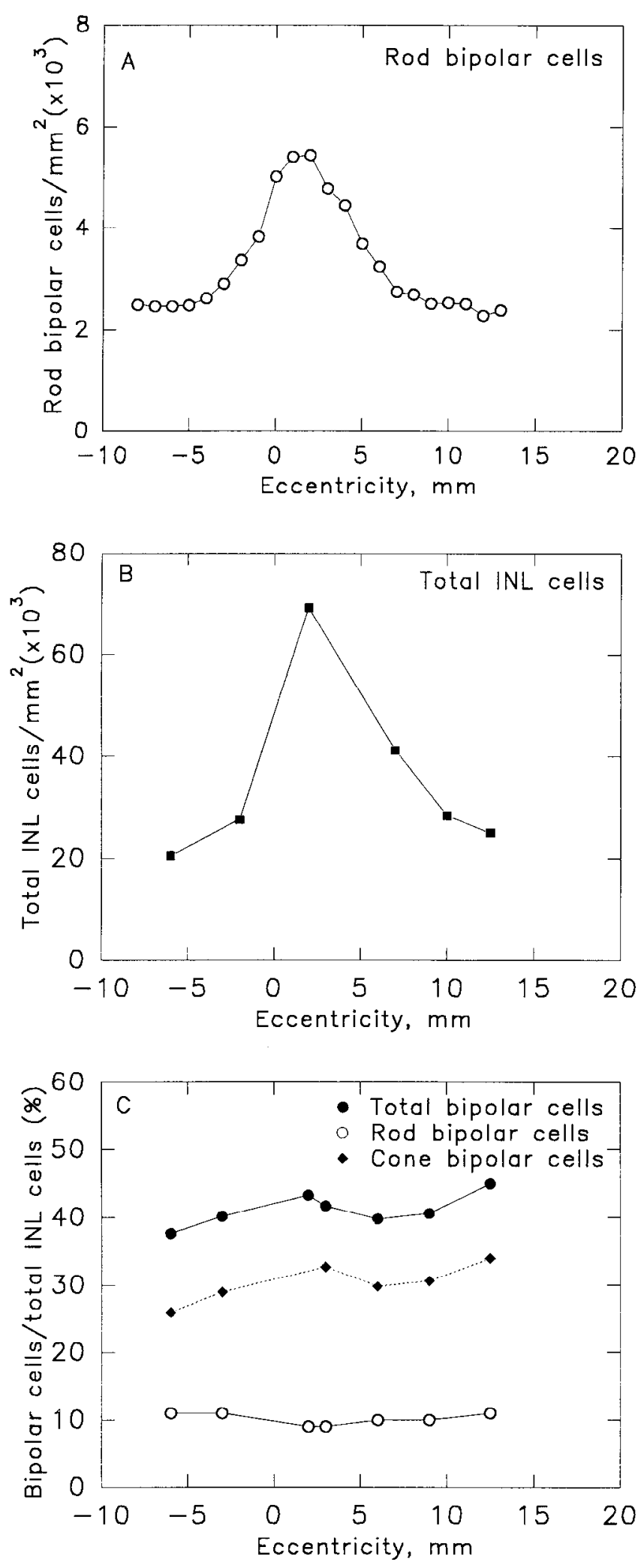

Figure 9. A, Density of rod bipolar cells in one retina, as identified by staining for PKC, and the total population of INL cells, as identified by staining with ethidium homodimer for the same retina. Eccentricity is expressed as distance from the optic nerve head. $B$, The total population of INL cells, as identified by staining with ethidium homodimer, in the same retina of $A$. $C$, Bipolar cells as a percentage of total INL cells (average of two retinas.). microcircuit must be rigidly controlled. It seems more important that each participant in the circuit be present in the correct proportion than that the retinal circuits be arranged at a predetermined absolute density across the back of the eye.

\section{How is the visual streak constructed?}

In the central retina of the rabbit, the density of all classes of retinal neuron is high, and the ratio of cones to rods is higher than in the periphery (Hughes, 1977; Young and Vaney, 1991). Since the streak is somewhat analogous to the fovea of primates or the area centralis of cats, one might have suspected that the ratio of bipolar cells to amacrine cells would be higher in the streak than the periphery. Instead, the ratio changed little across the retina. However, the expectation arises partly from the generalization that bipolar cells are part of the retina's "through pathway," while amacrines modulate the flow down that patha dichotomy invalidated by the discovery that amacrine AII is an authentic member of the retina's through pathway (Famiglietti and Kolb, 1975; Dacheux and Raviola, 1986; Smith et al., 1986; Sterling et al., 1988; Strettoi et al., 1990, 1992; Vaney et al., 1991; Grünert and Martin, 1991)). Our results are consistent with the idea that bipolar and amacrine cells participate equally in retinal activities requiring high spatial resolution. In other words, the higher visual acuity of the streak may arise primarily because the cells are densely packed, not because the neural circuitry of the retina is fundamentally different from that in the periphery.

In the visual streak, the total density of neurons is, indeed, much greater than in the periphery. From the periphery to the central retina, the total density of cells in the INL approximately triples. Three factors act in concert to create the heightened density. First, the sizes of the cells are smaller. In addition, the retina is thicker for all the retinal layers. Finally, the frequency of Müller cells is lower. Müller cells make up 34\% of the INL cells in the dorsal periphery but only $18 \%$ in the streak.

Another important difference is seen when one compares the gradients of INL neurons with that of the retinal ganglion cells. The density of ganglion cells declines more than 30 -fold from the peak of the streak to the periphery (Vaney, 1980; Masland et al., 1984; Peichl et al., 1987). The decline for bipolar and amacrine cells is never greater than fivefold. This means that the convergence of bipolar and amacrine cells is on average sixfold greater in the periphery than centrally.

\section{Partition between rod and cone bipolars}

The ratio of cone bipolars to rod bipolars varied from about 3 in the periphery to 4.5 in the streak; there were always more cone bipolars than rod bipolars. This was true despite the fact that the rabbit's retina is strongly rod dominated-even at the peak of the streak rods outnumber cones by more than 15:1 (Vaney et al., 1991). Nonetheless, the result seems fairly secure. The confocal double-label images clearly show that PKC-stained bipolar cells are the minority, and all available evidence indicates that PKC stains the whole population of rod bipolars (Grünert and Martin, 1991; Kolb et al., 1993).

Further evidence comes from comparison of our data to those obtained by other methods. Reichenbach et al. (1993) show that the average number of Müller cells in the adult rabbit is about 4 million per retina. If Müller cells represent approximately $25 \%$ of the total INL cells (Table 1), the total number of cells of the inner nuclear layer of the adult rabbit retina is in the range of 16 million. If, as we report here, rod bipolar cells represent $10 \%$ 


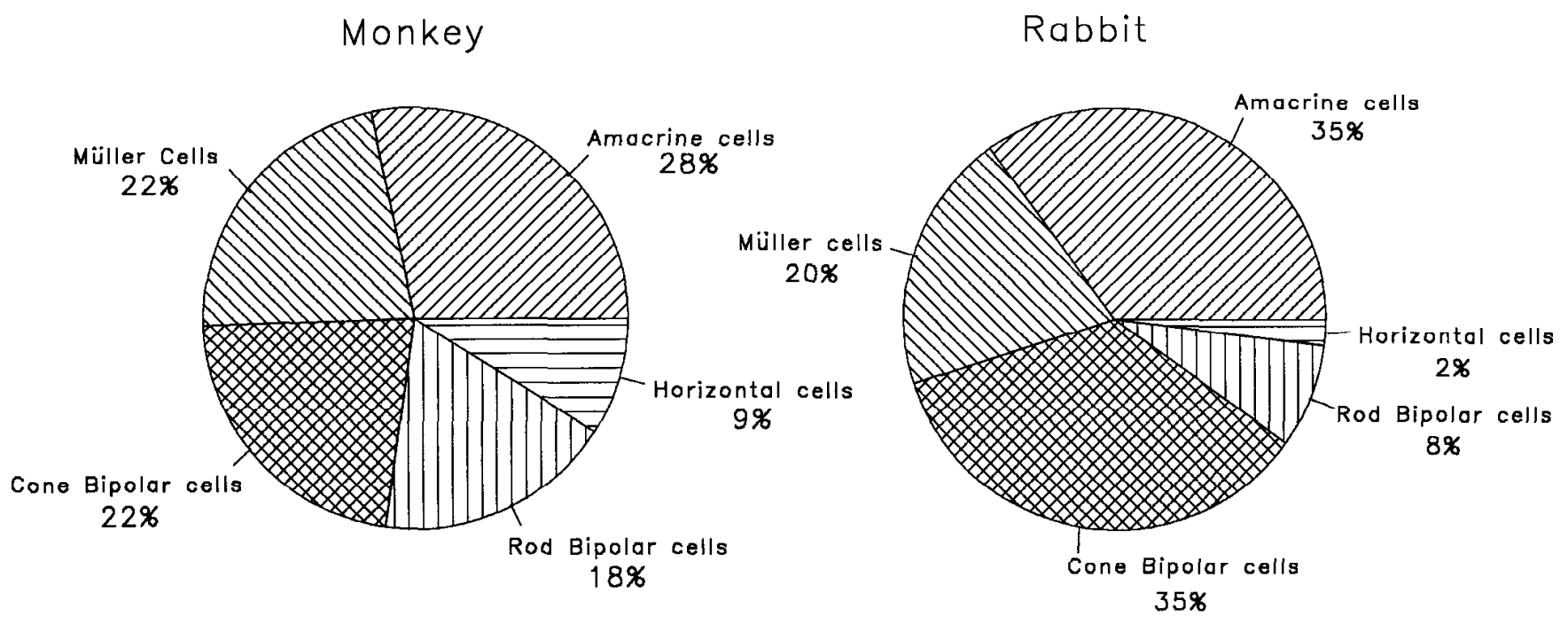

Figure 10. Fractions of bipolar, Müller, amacrine, and horizontal cells for the visual streak of the rabbit retina and for a point located at $5 \mathrm{~mm}$ temporal to the fovea of the monkey retina.

of the total INL cclls, the total number of rod bipolar cells should be 1.6 million. In fact, an independent measurement estimated an average of 1.7 million rod bipolar cells per rabbit retina (Young and Vaney, 1991).

While the predominance of cone bipolars seems counterintuitive, it is less so if one considers the organization of the rod and cone pathways. Many rods converge upon a rod bipolar; but few cones converge upon each cone bipolar.

\section{Comparison with the monkey}

Do mammalian retinas differ widely in their functional circuitry, or are the main differences those dictated by varying ratios of rods and cones? With this question in mind, we compared the relative numbers of retinal neurons in the monkey and rabbit. Data for the monkey are available from the study of Martin and Grünert (1992), who identified cells in serial semithin sections reacted for various immunohistochemical markers. While absolute numbers were not the main goal of their study (and uncertainties exist because of their counting methods-see below) the numbers are valid for the rough comparison sought here.

The retina of the monkey has a highly specialized fovea, while that of the rabbit is more uniform. The difference means that one cannot compare the two retinas at the same retinal eccentricities. A better comparison is between areas in which the ratio of cones to rods is the same. In the rabbit's visual streak, cones represent approximately $5 \%$ of all photoreceptors. The comparable point in the monkey lies at $5 \mathrm{~mm}$ eccentricity. For those locations, the fractions of horizontal, Müller, bipolar, and amacrine cells for the two species are shown in Figure 10.

The convergence of cones upon cone bipolar cells is quite similar in the two retinas. There are 2.8 to 3 cone bipolars for each cone in the monkey (Fig. $6 B$ of Martin and Grünert, 1992) and 1.9 in the visual streak of the rabbit. In contrast, the convergence of rods upon rod bipolars is much greater in the rabbit. The ratio of rods to rod bipolars in the monkey is approximately 12.5 to 1 (Grünert and Martin, 1991). In the rabbit, it is almost 50 to 1 . Another way to see this difference is to compare the ratio of cone bipolars to rod bipolars, which is almost 5 to 1 in the rabbit and is approximately 1.3 to 1 in the monkey. Relatively speaking, the rabbit's retina is poor in rod bipolar cells.

In contrast to the convergence of photoreceptors, the convergence of bipolar upon amacrine cells is very similar in the two retinas. The ratio of bipolar cells to amacrine cells in the monkey is approximately 1.3 to 1 (Figs. $4 A$ and 5 of Martin and Grünert, 1992). In the rabbit, it is 1.2 to 1 . The exact meaning of this close similarity will have to be learned from detailed comparison of the retinal microcircuits, since the calculation lumps together the rod and cone pathways. Generally speaking, though, it suggests that the main difference in the handling of visual information is in the pooling of information from the rod photoreceptors. Once that input has been collected by the rod bipolar cells, the numerical difference between the two retinas is slight.

\section{Strategies for analyzing cell populations}

To understand the retina's function, its cell populations must be rigorously described. Much progress has been made using the traditional anecdotal methods. However, the retina is par excellence a sampling system, in which each element is important because each represents an operation carried out upon input from a particular region of visual space. The ultimate goal must, thus, be to identify every cell in the retina's circuitry. To meet that goal, one must deal with the cells that are "invisible"those for which no specific stain now exists. Even if one cannot specifically stain all subclasses of cell, it is important to know at least how many unstained cells exist, because their potential effect is a factor in interpreting the retina's function. Furthermore, once their existence is known, specific methods for identifying them can be sought.

The problem is harder than it looks, primarily because of individual variations that occur between animals and between tissues treated with different histochemical methods. A successful approach has been to cut serial semithin sections and react them with a variety of antibodies. If long series are analyzed (Marc et al., 1990) an accurate sampling of the tissue is obtained. It is possible to do the same thing using small numbers of sections and Abercrombie corrections (Martin and Grünert, 
1992), but one then must accept the uncertainties introduced by the correction (for thin sections and short series, the magnitude of the correction is quite large). Perhaps the most important problem for both methods, however, is that relatively few antibodies may be used with etched semithin sections.

The approach used here was to divide the cells into their four main classes using methods independent of any histochemistry. Because we exhaustively accounted for the cells, it became possible to interconvert data obtained by a variety of histochemical methods, provided that the numbers of a specifically stained cell are measured relative to the total number of INL cells present at a given retinal location. As an example, we analyzed the distribution of rod bipolar cells using conventional immunohistochemically stained whole mounts. Confocal microscopy was used to establish the base of reference. This was a convenience (in about an hour we could obtain a complete series of micrographs of $1 \mu \mathrm{m}$ horizontal sections through the INL) but the same information would be available from serial semithin sections. At this point, one could carry out a similar analysis for finer subclasses of bipolar cells, or for the various populations of amacrine cells.

\section{References}

Boycott BB, Hopkins JM (1981) Microglia in the retina of the monkey and other mammals; its distinction from other types of glia and horizontal cells. Neuroscience 6:679-688.

Cohen E, Sterling P (1990) Demonstration of cell types among cone bipolar neurons of the cat retina. Philos Trans R Soc Lond [Biol] 330: 305-321.

Curcio CA, Allen KA (1990) Topography of ganglion cells in human retina. J Comp Neurol 300:5-25.

Dachcux RF, Raviola E (1986) The rod pathway in the rabbit retina: a depolarizing bipolar and amacrine cell. J Neurosci 6:331-345.

Dann JF, Buhl EH, Peichl L (1988) Postnatal dendritic maturation of alpha and beta ganglion cells in cat retina. J Neurosci 8:1485-1499.

Famiglietti EV, Kolb H (1975) A bistratified amacrine cell and synaptic circuitry in the inner plexiform layer of the retina. Brain Res 84:293-300.

Fernald RD (1990) Teleost vision: seeing while growing. J Exp Zool [Suppl] 5:167-180.

Grünert U, Martin PR (1991) Rod bipolar cells in the macaque monkey retina: immunoreactivity and connectivity. $J$ Neurosci 11:27422758.

Hughes A (1977) The topography of vision in mammals of contrasting life style: comparative optics and retinal organization. In: Handbook of sensory physiology (Crescitclli F, cd), pp 613-756. Berlin: Springer.

Jeon C-J, Masland RH (1993) Selective accumulation of diamidino yellow and chromomycin A3 by retinal ganglion cells. J Histochem Cytochem 41:1651-1658.

Kolb H, Nelson R, Mariani A (1981) Amacrine cells, bipolar cells, and ganglion cells of the cat retina: a Golgi study. Vision Res 21: 1081-1114.

Kolb H, Zhang L, DeKorver L (1993) Differential staining of neurons in the human retina with antibodies to protein kinase $\mathrm{C}$ isozymes. Vis Neurosci 10:341-351.

Krebs W, Krebs IP (1987) Quantitative morphology of the primate peripheral retina (Macaca irus). Am J Anat 179:198-208.

Krebs W, Krebs IP (1989) Quantitative morphology of the central fovea in the primate retina. Am J Anat 184:225-236.
Marc RE, Liu WL, Kalloniatis M, Raiguel SF, van Haesendonck E (1990) Patterns of glutamate immunoreactivity in the goldfish retina. J Neurosci 10:4006-4034.

Martin PR, Grünert U (1992) Spatial density and immunoreactivity of bipolar cells in the macaque monkey retina. J Comp Neurol 323: 269-287.

Masland RH (1988) Amacrine cells. Trends Neurosci 11:405-410.

Masland RH (1992) Cell mosaics and neurotransmitters. In: Principles and practice of ophthalmology: basic sciences (Albert DM, Jakobiec FA, eds). Philadelphia: Saunders.

Masland RH, Mills JW, Hayden SA (1984) Acetylcholine-synthesizing amacrine cells: identification and selective staining by using radioautography and fuorescent markers. Proc R Soc Lond [Biol] 223:79100.

Masland RH, Rizzo JF, Sandell JH (1993) Developmental variation in the structure of the retina. $\mathrm{J}$ Neurosci 13:5194-5202.

Mastronarde DN, Thibeault MA, Dubin MW (1984) Non-uniform postnatal growth of the cat retina. J Comp Neurol 228:598-608.

Negishi K, Kato S, Teranishi T (1988) Dopamine cells and rod bipolar cells contain protein kinase C-like immunoreactivity in some vertebrate retinas. Neurosci Lett 94:247-252.

Oyster CW, Takahashi ES (1977) Interplexiform cells in rabbit retina Proc R Soc Lond [Biol] 197:477-484.

Peichl L, Buhl EH, Boycott BB (1987) Alpha ganglion cells in the rabbit retina. J Comp Neurol 263:25-41.

Reichenbach A, Schnitzer J, Reichelt E, Osborne NN, Fritzsche B, Puls A, Richter U, Friedrich A, Knott A-K, Schober W, Timmermann U (1993) Development of the rabbit retina, III: differential retinal growth and density of projection neurons and interneurons. Vis Neurosci 10: $479-498$.

Repka MX, Quigley H.A (1989) The effect of age on normal human optic nerve fiber number and diameter. Ophthalmology 96:26-32.

Robinson SR, Dreher Z (1990) Müller cells in adult rabbit retinae: morphology, distribution and implications for function and development. J Comp Neurol 292:178-192.

Schnitzer J (1989) Enzyme-histochemical demonstration of microglia cells in the adult and postnatal rabbit retina. J Comp Neurol 282: 249-263.

Smith RG, Freed MA, Sterling P (1986) Microcircuitry of the darkadapted cat retina: functional architecture of the rod-cone network. J Neurosci 6:3505-3517.

Sterling P, Freed MA, Smith RG (1988) Architecture of rod and cone circuits to the on-beta ganglion cell. J Neurosci 8:623-642.

Stone J (1981) The wholemount handbook. Maitland: Gordon.

Strettoi E, Dacheux RF, Raviola E (1990) Synaptic connections of rod bipolar cells in the inner plexiform layer of the rabbit retina. J Comp Neurol 295:449-466.

Strettoi E, Raviola E, Dacheux RF (1992) Synaptic connections of the narrow-field bistratified rod amacrine cell (AII) in the rabbit retina. J Comp Neurol 325:152-168.

Vaney DI (1980) A quantitative comparison between the ganglion cell populations and axonal outflows of the visual streak and periphery of the rabbit retina. J Comp Neurol 189:215-233.

Vaney DI, Gynther IC, Young HM (1991) Rod-signal interneurons in the rabbit retina: 2. AII amacrine cells. J Comp Neurol 310:154169.

Wässle H, Boycott BB (1991) Functional architecture of the mammalian retina. Physiol Rev 71:447-480.

Wässle H, Yamashita M, Greferath U, Grünert U, Müller F (1991) The rod bipolar cell of the mammalian retina. Vis Neurosci 7:99112.

Young HM, Vaney DI (1991) Rod-signal interneurons in the rabbit retina: 1. Rod bipolar cells. J Comp Neurol 310:139-153. 